\title{
The Determination of the Relationship between Sportspersonship Orientations and Positive Thinking Levels of the Athletes Engaged in Different Sports Branches
}

\author{
Ünsal Tazegül ${ }^{*}$, Ozan Esmer \\ School of Physical Education and Sports, Mardin Artuklu University, Mardin, Turkey
}

Copyright $\mathrm{O} 2018$ by authors, all rights reserved. Authors agree that this article remains permanently open access under the terms of the Creative Commons Attribution License 4.0 International License

\begin{abstract}
The aim of this study is to reveal the relationship between sportspersonship orientations and positive thinking levels of the athletes in the team branch. In this study, Multidimensional Sportspersonship Orientation Scale and Positive Thinking Skills Scale were used as data collection tools. Portable IBM SPSS Statistics v20 software package was also used to analyze the data. For analyses of the data, descriptive statistics and Pearson correlation coefficient analysis were applied in the analysis of the data. As a result, it was determined that there is a positive relationship between athletes' positive thinking scores and adherence to social norms, respect for rules and officials and respect for opponent.
\end{abstract}

Keywords

Team Sports

\section{Introduction}

The concept of sportspersonship is related with normative standards on the relationship between social and moral values. Sportspersonship reveals virtuous behavioral tendencies that promote how to behave in accordance with the spirit of sports [1].

The concept of sportsperson refers the concept of competition and honesty as a responsible and thoughtful athlete, and it can be also expressed by concepts of supreme volunteerism, respect, kindness, outgoingness, compassion and generosity [2].

The concept of sportspersonship, in its general sense, is concerned with how athletes are guided to play the game. There are three theoretical approaches to how to understand sportspersonship. The first is socio-cognitive theory. In this theory, modelling and reinforcement determine the appropriate and non-competitive behavior of athletes in competitive situations. The second approach reveals the concepts and especially, moral logic in the structural development models. This approach demonstrates the influence of aggression on one person's capacity of reconciliation through moral dialogue, suggesting similar tendencies associated with sportspersonship. The last approach is socio-psychological approach. This approach has sports-based aspects of socio-psychological model. In the socio-psychological approach, there are three key elements and they are sportspersonship orientation, the development of the sportspersonship orientation and behaviors towards sportspersonship [3]. Vallerand and Loser explain the socio-psychological model as the relationship between sportspersonship and personal decision. [4].

A specific way of thinking can be defined as the way in which individuals choose and process information when interpreting the events they face in their lives. This style varies according to individual differences. While some individuals interpret an event in a positive way, another one may interpret the same event negatively [5]. The way of thinking is a kind of preference for the use of the talents that individuals possess. They choose a form of expressing or controlling themselves in any situation in which they meet [6]. Individuals, who have a positive thinking and are able to positively evaluate the events that they are experiencing on their surroundings, have more positive experiences than others and they are more successful in their lives and feel more energetic and happy in their activities [7].

According to Freitag (2003), an individual's thinking is one of the essential elements of her existence and has important functions like her organs. The general function of the ideas is to facilitate the adaption of the individual to the society and environment where he lives in, thereby 
increasing the possibility of subsistence. Individuals need to think positively depending on two important factors. Positive thinking is an important source of motivation and an important means of raising the quality of existence for the individual to continue his daily life. Positive thinking can be considered as the way of looking on the bright side of events. Positive thinking, a concept that includes general features, can be defined as a comprehensive attitude that reflects in the individual's speech, behavior, feelings, and thoughts [8].

Positive thinking, which is a cognitive process, helps individuals to use their skills effectively, to create positive images, to develop optimistic ideas, to find solutions to problems, to make positive decisions and to find more happiness in their lives. Positive thinking can be defined as using skills but it does not ignore the need to make realistic assessments [9]. On the contrary, positive thinking is a positive focus and interpretation after acknowledging the positive and negative aspects of events and situations that individuals face [10-11].

The aim of this study is to reveal the relationship between sportspersonship orientations and positive thinking levels of the athletes in the different branch.

\section{The Method}

\subsection{The Method of the Study}

In this study, quantitative method of research was used. The quantitative method of research is defined as a method of research that can be observed, measured, and numerically expressed by objectifying phenomena and events. The main aim in quantitative studies is to examine the social behaviors of people through observation, experiment, and test, and to quantify them numerically.

\subsection{The Sample}

A total of 251 athletes, 33 football players, 36 volleyball players, 40 handball players, 20 water polo, 30 swimming, 26 boxing, 36 athletics and 30 basketball players, who already ranked among the top three athletes in Turkish Championships, represent sample for the study.

\subsection{Data Collection Tools}

\subsubsection{Multidimensional Sportspersonship Orientation} Scale

The value of Cronbach Alpha was respectively 0,86 for Factor 1 (respect for social convention), 0,83 for Factor 2 (respect for rules and officials), 0,91 for Factor 3 (respect for one's full commitment) and 0,82 for Factor 4 (respect for opponents). The values were considered to be highly reliable [12].

\subsubsection{Positive Thinking Skills Scale}

Positive Thinking Skills Scale was developed by Bekhet and Zauszniewski in 2013. The Cronbach alpha value for internal consistency coefficient of the scale was found to be [13].

Table 1. The Findings of Descriptive Statistics

\begin{tabular}{|c|c|c|c|}
\hline & & Mean & Std. Deviation \\
\hline \multirow{8}{*}{ Positive thinking } & Football & 20,8182 & 2,75516 \\
\hline & Volleyball & 16,2778 & 3,96132 \\
\hline & Handball & 16,2667 & 3,61478 \\
\hline & Basketball & 18,1333 & 5,44933 \\
\hline & water polo & 21,5242 & 2,23658 \\
\hline & swimming & 17,5326 & 2,45897 \\
\hline & boxing & 16,5329 & 3,98324 \\
\hline & athletics & 15,3678 & 4,57842 \\
\hline \multirow{8}{*}{$\begin{array}{l}\text { Respect for social } \\
\text { convention }\end{array}$} & Football & 20,6667 & 2,94392 \\
\hline & Volleyball & 20,2000 & 3,96900 \\
\hline & Handball & 19,7857 & 2,96592 \\
\hline & Basketball & 20,6425 & 4,56175 \\
\hline & water polo & 21,2369 & 3,54782 \\
\hline & swimming & 21,5368 & 3,20140 \\
\hline & boxing & 18,1578 & 3,23045 \\
\hline & athletics & 20,2597 & 5,98010 \\
\hline \multirow{8}{*}{$\begin{array}{l}\text { Respect for rules and } \\
\text { officials }\end{array}$} & Football & 21,6364 & 2,40855 \\
\hline & Volleyball & 19,8857 & 3,41942 \\
\hline & Handball & 21,9286 & 1,49174 \\
\hline & Basketball & 19,8000 & 5,00286 \\
\hline & water polo & 20,3002 & 2,02365 \\
\hline & swimming & 18,1523 & 3,301020 \\
\hline & boxing & 20,3690 & 1,36981 \\
\hline & athletics & 18,1578 & 5,32519 \\
\hline \multirow{9}{*}{$\begin{array}{l}\text { Adherence to } \\
\text { responsibilities in sports }\end{array}$} & Football & 21,4242 & 2,88347 \\
\hline & Volleyball & 21,5429 & 3,00336 \\
\hline & Handball & 22,9231 & 1,18754 \\
\hline & Basketball & 22,5333 & 4,48596 \\
\hline & water polo & 20,2365 & 2,02365 \\
\hline & swimming & 20,0235 & 2,32549 \\
\hline & boxing & 21,5301 & 3,39256 \\
\hline & athletics & 21,2003 & 2,03695 \\
\hline & & Mean & Std. Deviation \\
\hline \multirow{8}{*}{ Respect for opponents } & Football & 21,1563 & 2,71328 \\
\hline & Volleyball & 18,9714 & 3,98147 \\
\hline & Handball & 18,7143 & 2,19890 \\
\hline & Basketball & 19,8667 & 4,71876 \\
\hline & water polo & 20,0369 & 2,71328 \\
\hline & swimming & 17,5960 & 3,98147 \\
\hline & boxing & 18,3028 & 2,19890 \\
\hline & athletics & 18,4203 & 4,71876 \\
\hline
\end{tabular}

\subsection{The Analysis of Data}

For analyses of the data, Portable IBM SPSS Statistics 
v20 software package was used. The Kolmogorov-Smirnov Test was applied in order to decide whether data has normal distribution and ANOVA-Homogeneity of variance was applied to test the homogeneity of variances and it is observed that data is homogeneous and has a normal distribution. After this initial analysis, it was decided to use the parametric test method in statistical analysis of the data. For the analysis of data, the descriptive statistics and Pearson Correlation analysis were used to analyze the collected data.

\section{Findings}

As a result of descriptive statistics analysis it was determined that the highest score in positive thinking belongs to the football players and the lowest score belongs to the athletics players; the highest score in adherence to the social norms belongs to the swimming players and the lowest score belongs to the boxing players; the highest score in respect for rules and management belongs to handball players and the lowest score belongs to swimming. it is determined that the highest score in adherence to responsibilities in sports belongs to basketball players and the lowest score belongs to the swimming players, and the highest score in respect for opponent belongs to football players and the lowest score belongs to the swimming players.

Table 2. Correlation analysis

\begin{tabular}{|c|c|c|}
\hline & & Positive thinking \\
\hline \multirow{2}{*}{$\begin{array}{l}\text { Respect for social } \\
\text { convention }\end{array}$} & $\begin{array}{c}\text { Pearson } \\
\text { Correlation }\end{array}$ &, $455^{* *}$ \\
\hline & $\mathrm{p}$ &, 001 \\
\hline \multirow{2}{*}{$\begin{array}{c}\text { Respect for rules and } \\
\text { officials }\end{array}$} & $\begin{array}{c}\text { Pearson } \\
\text { Correlation }\end{array}$ &, $628^{* *}$ \\
\hline & $\mathrm{p}$ &, 000 \\
\hline \multirow{2}{*}{$\begin{array}{l}\text { Adherence to } \\
\text { responsibilities in } \\
\text { sports }\end{array}$} & $\begin{array}{c}\text { Pearson } \\
\text { Correlation }\end{array}$ &, 257 \\
\hline & $\mathrm{p}$ &, 102 \\
\hline \multirow{2}{*}{$\begin{array}{l}\text { Respect for } \\
\text { opponents }\end{array}$} & $\begin{array}{c}\text { Pearson } \\
\text { Correlation }\end{array}$ &, $678^{* *}$ \\
\hline & $\mathrm{p}$ &, 000 \\
\hline
\end{tabular}

As a result of the correlation analysis carried out, it was determined that there is a statistically significant relationship between athletes' positive thinking levels, and adherence to social norms, respect for rules and management, and respect for opponent.

\section{Discussion and Conclusions}

According to the results of descriptive statistical analysis, it was determined that the positive thinking score of football players is better than the other athletes in the scope of the study. In the light of data, it can be said that football players have more positive thoughts against the problems they face and they exhibit more constructive attitudes because positive thinking can be defined as a state of well-being in terms of different aspects such as happiness and morale [14].

As a result of descriptive statistics analysis it was determined that the highest score in adherence to the social norms belongs to the swimming players and the lowest score belongs to the boxing players. In the light of data, it can be said that it is not important the end of the game for the swimming. It is important for them to compete friendly by following sport the rules. As a result of descriptive statistics analysis it was determined that the highest score in respect for rules and management belongs to handball players and the lowest score belongs to swimming. It can be said that the athletes in the handball branch are more respectful to the decisions of the judges and the administration. It is determined that the highest score in adherence to responsibilities in sports belongs to basketball players and the lowest score belongs to the swimming players. It can be said that the athletes in the basketball branch fulfill their responsibility for more related to sports. It is determined that the highest score in respect for opponent belongs to football players and the lowest score belongs to the swimming players. According to this statistic, it can be said that swimming are more respectful to the opponents.

Scott (1997) studied the attitudes and principles of female athletes, called sub-elites, in his work. As a result, it was determined that female athletes have a greater desire to win rather than their talents. When the athletes' thoughts were examined, it was observed that they had the opinion like "you cannot do it if you do not plan to do something very well. If you really want to achieve it then you can achieve it". Therefore, women athletes have achieved success due to positive thinking [15].

Tazegül (2016a) determined a positive relationship between body appreciation levels and positive thinking scores of tennis players. In addition, the positive thinking score of tennis players was determined as 17,125 . It was determined that the highest score achieved in the adherence to social norms belongs to football players. Therefore, it can be said that football players are more likely to congratulate their opponents and to appreciate their competitors' performances after competition [16].

Miller et al. (2004) determine that the score of respect for social convention of young athletes was found to be 3.50 [17]. Stornes and Ommundsen (2004) found the score of respect for social convention of young handball players as 4.13 [2].

It has been determined that the highest score belongs to handball players in terms of respect for rules and officials. In the light of data, it can be said that handball players are more respectful to referees and referees' decisions, even in their faulty decisions. Gürpınar and Kurşun (2013) 
found that basketball players' respect for rules and management was higher than football players [18].Tsai \& Fung (2005) revealed that basketball players regard sportsmanship less than volleyball players. It has been determined that the highest score in terms of adherence to the responsibilities belongs to the basketball players. Therefore, it can be said that the athletes engaged in the basketball branch became more willing to work out in order to fulfill their struggle and responsibilities during competition [19]. SSenel and Yildiz (2016) determined that the score of the adherence to responsibilities in sports of athletes in team sports was found to be 4.41 . It has been determined that the highest score in terms of respect for opponent belongs to the football players [20]. Sezen and Yıldıran found a statistically significant difference between the level of adherence to responsibilities in sports and the average of empathic thoughts of football players in their studies in 2011 [21].

As a result of the correlation analysis carried out, it was determined that there is a positive relationship between athletes' positive thinking scores and adherence to social norms, respect for rules and officials and respect for opponent. When this result is evaluated according to the concepts of positive thinking and sportspersonship, it is thought that this result is normal. Because the athlete who has a positive opinion can evaluate the events more positively Therefore, they may exhibit more sportsmanlike behavior.

Lemyre et al. (2002) found that high ego-oriented athletes exhibited low level of sportspersonship behaviors. They also determined that high ego-oriented athletes had little respect for the rules and officials of the match and they displayed deceptive behaviors in order to reach their goals [22].

Duda and his colleagues (1991) found that high ego-oriented female and male basketball players exhibited unsporting and aggressive behaviors [23]. Kavussanu and Roberts (2001) reported that high ego-oriented high school basketball players exhibited unsporting behaviors when they had a fear of failure in a competition [24].

As a result, it was determined that there is a relationship between positive thinking levels and sportsmanship orientations of athletes. When this result is evaluated according to the concepts of sportspersonship and positive thinking, it is thought that this result is normal. Because as positive thinking levels of athletes increase, they tend to approach the events more positively and this affects their sportspersonship behaviors. In addition, as a result of the literature review, no study was found that directly revealed the relationship between positive thought levels and sportspersonship orientations of athletes. In this respect, it is thought that this study will contribute greatly to the literature and it will constitute an example of more comprehensive work to be done thereafter.

\section{REFERENCES}

[1] Stornes, T \& Bru, E. (2002).Sportspersonship and Perceptions of Leadership: An Investigation of Adolescent Handball Players' Perception of sportspersonship and Associations with Perceived Leadership", European Journal of Sport Science, 2(6), pp. 1-15.

[2] Stornes, T., Ommundsen, Y. (2004).Achievement Goals, Motivational Climate and Sportspersonship: a Study of Yound Handball Players", Scandinavian Journal of Education, 48(2), pp. 205-221.

[3] Vallerand RJ \& Losier GF. (1994). Self-Determined Motivation and Sportsmanship Orientation: An Assessment of Their Temporal Relationship. Journal of Sport \& Exercise Psychology; 16: 229-245.

[4] Chantal Y and Bernache-Assollant I. (2003). A Prospective Analysis of Self-Determined Sport Motivation and Sportspersonship Orientations. Athletic Insight. The Online Journal of Sport Psychology; 5(4)

[5] Erez, A., Johnson, D. E \& Judge, T.A. (1995) Self-decepti on as a mediator of the relationship between dispositions and subjective well-being, Personality and Individual Differences, 5, 597-612.

[6] Çubukçu, Z. (2004). The effect of teacher candidates' preference for learning styles of thinking styles, XIII. National Educational Sciences Congress, 6-9 July, İnönü University, Faculty of Education, Malatya

[7] Tazegül, Ü. (2016). The Determination of the Relationship between the Elite Level Tennis Players' Positive Thinking Level and Body Admiration, Cilt: 5, Say1: 8, 2906-2912.

[8] Freitag, F. E. (2003). Positive thinking is a way of getting rid of negative influences,, (Çev. Uğur Önder).İstanbul: Omega Yayınları.

[9] McGrath, P. (2004). The burden of "RA RA" positive: survivors' and hospice patients' reflection on maintaining a positive attitude to serious illness, Support Care Cancer, 12, 25-33.

[10] Bekhet, A. K ve Zauszniewski, A. (2013). Measuring use of positive thinking skills: Psychometric testing of a new scale, Western Journal of Nursing Research, 35(8) 1074-1093.

[11] Tod, A., Warnock, C., \& Allmark, P. (2011). A critique of positive thinking for patients with cancer, Nursing Standard, $25,43-47$

[12] Sezen-Balçıkanlı, G. (2010). The Turkish Adaptation of Multidimensional Sportspersonship Orientation Scale-Msos: A Reliabilitiy and Validity Study, Journal of Gazi Physical Education and Sports Sciences, XV (1), 1-10.

[13] Akın, A., Uysal, R., \& Akın, Ü. (2015). The Validity And Reliability Of Turkish Version Of The Positive THINKING SKILLS SCALE Akademik Bakış Uluslararası Hakemli Sosyal Bilimler Dergisi, 51, 265-270.

[14] Vara, Ş. (1999). "Investigation of Relations between Job Satisfaction and General Life Satisfaction in Intensive Care Nurses". Published Higher Education Thesis, Ege University, Institute of Health Sciences. İzmir. 
[15] Scott, D. (1997).Toiling in Obscurity. Women's Sports\& Fitness. 19(6):37-40.

[16] Tazegül, Ü. (2016a). The Determination Of The Relationship Between The Elite Level Tennis Players' Conduct Of Life and heir Admiration On Their Bodies, $4,32, .468-474$.

[17] Miller W.B, Roberts C and Ommundsen Y. (2004). Effect of Motivational Climate on Sportspersonship among Competitive Youth Male and Female Football Players. Scandinavian Journal of Medicine \& Science in Sports, 14: 193-202.

[18] Gürpınar, B \& Kurşun, S (2013). Sportspersonship Orientations of Basketball and Soccer Players III/1, 171-176.

[19] Tsai, E., \& Fung, L. (2005). "Sportspersonship in Youth Basketball and Volleyball Players". Athletic Insight: The Online Journal of Sport Psychology, 7 (2), 37-46. Kaynak: http://www. Athleti cinsight. com/Vol7Iss2/Sportspersonsh ip.htm
[20] Senel, E \& Yildiz, M (2016). The Investigation of Bodily/Kinesthetic Intelligence and Sportspersonship Orientation of Students in School of Physical Education And Sport, International Refereed Academic Journal of Sports, Health and Medical Sciences, summer 19, 54-61.

[21] Sezen-Balçıkanlı, G., Yıldıran, İ. (2011). Sportspersonship Orientation and Empathic Dispositions of Professional Soccer Players, SPORMETRE Beden Eğitimi ve Spor Bilimleri Dergisi, IX (2) 49-56.

[22] Lemyre P.N, Roberts G.C and Ommundsen Y. (2002). Achievement Goal Orientations, Perceived Ability, and Sportspersonship in Youth Soccer. Journal of Applied Sport Psychology, 14(2): 120-136.

[23] Duda J.L, Olson L.K and Templin T.J. (1991). The relationship of task and ego orientation to sportmanship attitudes and the perceived legitmacy of injurious acts. Res Q Exerc Sport, 62: 79-87.

[24] Kavussanu M and Roberts G.C. (2001).Moral functioning in sport: an achievement goal perspective. J Sport Exerc Psychol, 23: 37-54. 